\title{
BADANIA ZAANGAŻoWANE
}

\author{
Magda Wieteska \\ Instytut Pedagogiki, Uniwersytet Wrocławski \\ ul. Dawida 1, 50-527 Wrocław \\ E-mail: mag.wieteska@gmail.com \\ ORCID: https://orcid.org/0000-0002-1174-609X
}

\begin{abstract}
Abstrakt
Teza. Badania etnograficzne oraz badania w działaniu wykorzystywane są w wielu dziedzinach nauki, takich jak antropologia, socjologia, psychologia, medycyna, edukacja.W artykule została przybliżona istota tych metodologii, możliwości ich stosowania, a także łączenia.

Omówione koncepcje. W artykule omówiono istotę i przebieg badań w działaniu oraz rodzaje i poziomy etnografii edukacyjnej.Wyjaśniono potrzebę stałego monitoringu action research (Pilch, Bauman, 2010). Wskazano wyznaczniki prawidłowego opisu etnograficznego (Červinková, 2013).

Wyniki i wnioski. Etnografia edukacyjna przypomina ideę badań w działaniu. Podobnie jak badania w działaniu skupia się na dostrzeżeniu potrzeby zmiany i wprowadzeniu usprawniających rozwiązań.

Oryginalność. Oba typy badań są badaniami uczestniczącymi, cechującymi się zaangażowaniem badacza i badanych. Są istotne zwłaszcza dla nauk pedagogicznych ze względu na ich charakter: uczestniczący, interwencyjny i refleksyjny.Pozwalają dokładnie poznać i zrozumieć badany odcinek rzeczywistości społecznej.

Słowa kluczowe: etnografia edukacyjna, badania etnopedagogiczne, action research, obserwacja, diagnoza.

\section{Engaged research}

Abstract

Thesis. Ethnographic research and research in action are used in many fields of science. However, they rarely appear in pedagogy. The author of the article describes these methodologies, indicating the possibilities of their use as well as triangulation.

Concepts Discussed. The article discusses the essence and course of research in action as well as the types and levels of educational ethnography.

Results and conclusions. Educational ethnography resembles the idea of research in action. Similarly to research in action, it focuses on recognizing the need for change and introducing streamlining solutions. 
Originality. Both types of research are participatory research, characterized by the involvement of the researcher and the respondents.

Keywords: educational ethnography, ethnopedagogical research, action research, observation, diagnosis.

\section{ACTION RESEARCH - BADANIA W DZIAEANIU}

Funkcja diagnostyczna pedagogiki służy zarówno budowaniu teorii, jak i praktyki pedagogicznej. Pisze o tym Danuta Skulicz (1998), wyjaśniając, iż uzyskane w trakcie diagnozowania dane są materiałem informacyjnym o ich przeszłym i aktualnym stanie, a jednocześnie stanowią podstawę do czynności podejmowanych $\mathrm{w}$ trakcie doskonalenia teorii oraz praktyki pedagogicznej, takich jak: wyjaśnianie, porównywanie, modyfikowanie, prognozowanie. Diagnoza pedagogiczna służy tym samym budowaniu teorii eksplikacyjno-opisujących i teorii prakseologicznych, a efektem działań diagnostycznych jest diagnoza zawierająca rozpoznanie i krytyczne opracowanie danych (Skulicz, 2009).

Prakseologia jako nauka sprawnego działania dzięki zastosowaniu action research umożliwia preanimację (fazę oglądu), animację i ewaluację w konkretnej rzeczywistości społecznej, prowadząc do wykształcenia zmiany będącej odpowiedzią na odczuwany dyskomfort. W ten sposób badacz, działając, chce zastąpić mniej zadowalający stan rzeczy bardziej zadowalającym (Jabłoński, 2016). Badania w działaniu są zatem skupione na dostrzeżeniu potrzeby zmiany i wprowadzeniu usprawniających rozwiązań zgodnie z paradygmatem badań aktywizujących zakładającym, że taka zmiana jest nie tylko dopuszczalna, ale wręcz pożądana (Dudkiewicz, 2011). Ich celem nie jest więc wyłącznie samopoznanie, ale ulepszenie rzeczywistości społecznej.

Historia action research sięga końca XIX w. i obejmuje dwie fazy. Pierwsza z nich, datowana na lata 1920-1950 i związana z osobą Kurta Lewina (1948), polegała na weryfikacji efektywności teorii naukowych w celu wywołania pozytywnej zmiany społecznej i przebiegała według spirali: planowanie, działanie, ustalanie faktów na temat rezultatu działania. $Z$ kolei druga faza badań w działaniu rozpoczęła się w latach 70. w Wielkiej Brytanii. Zasięgiem objęła badania nad programami nauczania, w których nauczyciele przyjęli rolę badaczy własnej praktyki i programów nauczania. Hana Cervinková (2012) tłumaczy różnice między tymi dwoma podejściami zastąpieniem pozytywistycznej metodologii badań podejściem interpretatywnym. Action research zostały zaliczone do metod jakościowych, a badacze z teoretyków zmienili się w uczestników i praktyków własnych badań, „zanurzonych w badanych zjawiskach, lecz poprzez swą aktywną postawę próbujących je przekształcić" (Pilch, Bauman, 2010, s. 308). Sama nazwa: action research wskazuje zresztą ich istotę, czyli aktywne działanie możliwe dzięki zaangażowaniu (action) oraz systematycznej pracy nastawionej na poznanie danego zjawiska (research). Warto podkreślić, że działania zmierzające do poprawienia konkretnego wycinka rzeczywistości społecznej dotyczą wszystkich zaangażowanych w proces badawczy, a więc i badaczy, i badanych. Łączą działania i refleksję, teorię i praktykę, wspierają rozwój jednostki oraz całych społeczności (Červinková, 2012). Mają więc charakter uczestniczący (badacz i badani), oparty na współpracy (badacz i badani znajdują się we wspólnej przestrzeni działa- 
nia), podmiotowy (badani nie są przedmiotem, a podmiotem badań), interwencyjny (zmiana dysfunkcjonalnego wycinka rzeczywistości społecznej) oraz refleksyjny (namysł zarówno nad działaniami, jak i sytuacjami, w których zostały przeprowadzone). Tadeusz Pilch i Teresa Bauman (2010) zauważaja, że badania te zostawiają po sobie trwały ślad w postaci zmiany w środowisku - trwały, bowiem niekończący się z chwilą zakończenia badań.

\section{Przebieg procesu badawCZego}

Badania w działaniu mogą być prowadzone zarówno przez jednego badacza, jak i zespół badawczy. Ich rola jest $\mathrm{w}$ action reserach niezwykle istotna, bowiem to na badaczach spoczywa główny ciężar badania, jego powodzenie (Woynarowska-Sołdan, 2014). Badacz powinien zatem posiadać nie tylko wiedzę ekspercką dotyczącą danego problemu (i stale ją uzupełniać, i rozwijać), ale również umiejętność komunikacji zwłaszcza uważnego i empatycznego słuchania - pozwalającą budować pozytywne relacji międzyludzkie; zdolność do wnikliwej obserwacji, mediacji, a także taki sposób wejścia w badane środowisko, aby nie zaburzać jego istniejącej struktury. Jest on $\mathrm{w}$ tym badaniu nie tyle ekspertem, co inspiratorem do podejmowania odpowiednich działań przez osoby badane, swoistym facylitatorem, autentycznie zaangażowanym w proces badawczy. Maciej Jabłoński (2016) sytuuje badacza w działaniu jako osobę „między spacerowiczem a ankieterem”, traktującego rzeczywistość jako obszar możliwości. Jest więc badacz baumanowskim spacerowiczem, ale także ankieterem, gdyż „pytanie w ankiecie może czasami mieć większy ciężar normatywny niż wywiad narracyjny" (s. 249).

Action research przebiegają $\mathrm{w}$ formie cyklicznej spirali przy zachowaniu kolejności poszczególnych czynności. Pierwszą z nich jest pojawienie się problemu - dostrzeżenie dysfunkcyjności wycinka rzeczywistości społecznej i chęć jego naprawy (lub poprawy). W fazie drugiej - rozpoznania - badacz zbiera informacje na temat, którym chce się zajać: poprzez opis zastanej sytuacji (etap pierwszy) oraz poszukiwanie przyczyn jej dysfunkcjonalności (etap drugi). Kolejnym krokiem jest planowanie zmian z uwzględnieniem opinii badanych (czyli osób, których zmiany bezpośrednio dotyczą) oraz środków niezbędnych do przeprowadzenia badań (należy wziąć pod uwagę bezpieczeństwo badanych, przeprowadzić kwerendę literatury przedmiotu w zakresie zastosowanych metod w podobnych przypadkach). Kolejnym etapem badań jest działanie, czyli wprowadzenie uprzednio przygotowanego planu w życie. T. Pilch i T. Bauman (2010) radza, aby prowadzić ciągły monitoring w celu sprawdzania, czy oczekiwane rezultaty pojawiają się lub nie pojawiają oraz czy (i jakie) wystąpiły inne, niezamierzone efekty wdrożenia zmiany. Pomocne będą tu wywiady z badanymi, np. wywiad skoncentrowany na problemie. $\mathrm{W}$ fazie refleksji może pojawić się potrzeba powrotu do poprzednich etapów badań -wtedy, gdy wprowadzona zmiana nie przyniosła spodziewanych korzyści. W sytuacji, gdy nastąpiła pozytywna zmiana, badacz przechodzi do etapu integrowania wiedzy zdobytej w trakcie badania $\mathrm{z}$ wiedzą naukową (analiza i interpretacja wyników badań, porównywanie ich z istniejącym stanem w literaturze przedmiotu). Ostatni etap action research stanowi metarefleksja nad przedmiotem badań, podsumowująca wcześniejsze refleksje na każdym z etapów badania.

Ogrody Nauk i Sztuk nR 2020 (10) 
Wyniki badania z użyciem action research nie prowadzą do uniwersalnej prawdy (Woynarowska-Sołdan, 2014).Odnoszą się do konkretnej grupy i konkretnego proble$\mathrm{mu}$, dlatego też nie można ich $\mathrm{w}$ pełni generalizować, można natomiast wskazywać pola działania w celu zachęcenia innych badaczy do podjęcia tego rodzaju badań.

\section{BADANIA ETNOPEDAGOGICZNE}

Badania etnograficzne prowadzone są $\mathrm{w}$ takich dziedzinach nauki jak m.in. antropologia, socjologia, psychologia, medycyna, edukacja. Wykorzystuje się je coraz częściej w badaniach placówek edukacyjnych w zakresie takich problemów jak np. kultura szkoły, na którą składają się relacje między członkami szkolnej społeczności, elementy organizacji życia szkolnego czy funkcje wydzielonych przestrzennie pomieszczeń (Nowotniak, 2011). Etnografia edukacyjna, nazywana również badaniami etnopedagogicznymi, skupia się na rzeczywistości ludzi w szczególnej sytuacji życiowej - edukacyjnej (Dejna, 2012). Przedmiotem badań jest więc edukacja, czyli kształcenie i wychowanie, a perspektywą kontekst etnograficzny. Dagna Dejna (2012) w ramach etnografii edukacyjnej wyróżnia etnografię edukacji i etnografię w edukacji. Pierwsza z nich zajmuje się poszukiwaniem odpowiedzi na pytanie, czym jest edukacja dla członków danej grupy, w drugiej badana jest kulturowa i społeczna dynamika placówki.

Aby badania pedagogiczne można było umieścić $\mathrm{w}$ obrębie badań etnograficznych (etnopedagogicznych) badacz powinien podjąć próbę jak najgłębszego poznania rzeczywistości danej placówki edukacyjnej, starając się przebywać przez dłuższy czas $\mathrm{z}$ osobami będącymi przedmiotem obserwacji $-\mathrm{w}$ ich naturalnym środowisku, a więc w tym przypadku -w konkretnej placówce. Prowadząc obserwację powinien rozmawiać z ludźmi, by poznać ich punkt widzenia na określone kwestie, badać dokumenty, sporządzać dokumentację. W ten sposób, identyfikując elementy kultury, którą bada, dąży do zrozumienia świata osób badanych. Ma możliwość udziału w doświadczeniach uczniów i nauczycieli oraz obiektywnego oglądu ich wspólnych działań (Polak, 2007). Może więc obserwować różnorodne interakcje: walkę, negocjacje, manipulacje i na podstawie obserwacji oraz krytycznej refleksji budować obraz szkoły.

\section{Autoetnografia}

Specyficznym rodzajem etnografii są badania autoetnograficzne, będące połączeniem autobiografii i etnografii. Ze względu na brak zgodności co do proporcji ich łączenia, badacze mają tu pewną dowolność i tak ,jedni skupiają się na osobistych przeżyciach autora [stanowisko subiektywne], [a] inni kontekstualizują je w doświadczeniach zbiorowych [stanowisko realistyczne]" (Bielecka-Prus, 2014, s. 78). Istnieje także pogląd, że podział na autobiografię i etnografię nie jest możliwy, ponieważ we wszystkie badania włączane są osobiste doświadczenia badacza.

Ciekawym przykładem autoetnografii jest projekt badawczy opisujący społeczny świat wspinaczki, bazujący na podejściu autoetnografii analitycznej (Kacperczyk, 2016a). W podejściu tym badacz jest pełnym uczestnikiem badanych sytuacji, a jego aktywność poznawcza przebiega wzdłuż gromadzenia danych (obserwacja uczestnicząca, autoobserwacja, wywiady, dane zastane, praca ze źródłami danych) 
oraz ich późniejszego porównywania (doświadczenia własne, doświadczenia badanych). Autoetnografia umożliwia badaczowi „zanurzenie w studiowanym fenomenie" (Kacperczyk, 2016b) oraz scalenie "spojrzenia na zewnątrz ze spojrzeniem do wewnątrz" (Bielecka-Prus, 2014). Wiąże się to z funkcją terapeutyczną badań autoetnograficznych, będącą polem do zmiany w zakresie własnego życia i pisania jego pozytywnych scenariuszy.

\section{ETNOGRAFIA EDUKACYJNA}

Badania etnograficzne, nazywane też terenowymi, prowadzone są w celu opisu mniejszych lub większych grup w ich naturalnym środowisku. Działania badacza polegają na obserwacji codziennego życia badanych społeczności. Magdalena Cuprjak (2014) podkreśla wagę kategorii codzienności, gdyż udział w rutynowych czynnościach pozwala na poznanie zachowań uczestników badań, a także umożliwia poznanie przyczyn ich postępowania.

Etnograf poznaje badaną jednostkę lub społeczność głównie poprzez obserwację uczestnicząca, polegającą na jego współudziale w życiu badanej społeczności. Wskazana metoda zbierania danych jest jednak niewystarczająca, ponieważ opisowi brak przedstawienia etnograficznego, który jest „,wielopoziomową interpretacją zdarzeń obserwowanych przez etnografa podczas pobytu w terenie" (Červinková, 2013, s. 128). Do jego najważniejszych wyznaczników zalicza się: szczegółowość, kontekstowość, interpretacyjność i międzykulturową perspektywę. Tylko prawdziwie wnikliwa obserwacja prowadzi do szczegółowego i dokładnego opisu, którego powinno się dokonywać z różnych perspektyw, aby uzyskać najbardziej obiektywny ogląd sprawy. Te perspektywy, poziomy H. Červinková (2013) nazywa „sposobem patrzenia” i „sposobem widzenia". Pierwszy związany jest z technikami i metodami, drugi zaś z przypisywaniem znaczeń obserwowanym zjawiskom, „,które w momencie zapisania są już gęstymi interpretacjami kulturowej rzeczywistości widzianej przez etnografa" (Angrosino, 2010, s. 19). „Sposób znaczenia” nabiera głębi, gdy dołącza do niego krytyczna refleksja wzmocniona dodatkowo poprzez zaangażowane uczestnictwo badacza w procesie badawczym.

\section{Podsumowanie}

Zarówno badania w działaniu, jak i badania etnograficzne mają charakter uczestniczący, interwencyjny i refleksyjny. $W$ obu rodzajach badań badacz znajduje się we wspólnej przestrzeni działania $\mathrm{z}$ badanymi, w ten sposób docierając do badanego odcinka rzeczywistości społecznej w celu jak najdokładniejszego poznania oraz najgłębszego zrozumienia go. W etnografii - mimo że badacz najczęściej bada całą placówkę edukacyjną - podczas prowadzenia obserwacji rozmawia z ludźmi, poznając ich punkt widzenia.

Charakter interwencyjny przejawia się natomiast $\mathrm{w}$ dostrzeżeniu dysfunkcyjności wycinka rzeczywistości społecznej i nakreśleniu pozytywnych zmian. Oba typy badań cechują także głęboki namysł i refleksja. W przypadku ostatniego etapu action research jest to metarefleksja nad przedmiotem badań, podsumowująca wcześniejsze refleksje 
na każdym z etapów badania. Takie podejście nazywa się etnografią zaangażowaną -zaangażowanie jest tu widoczne nie tylko $\mathrm{w}$ bezpośrednim uczestnictwie, ale przy takim udziale badacza, by wywołać (pozytywną) zmianę w badanej rzeczywistości. Przypomina to ideę badań $\mathrm{w}$ działaniu, skupionych na dostrzeżeniu potrzeby zmiany i wprowadzeniu usprawniających rozwiązań, i często właśnie tak, w powiązaniu z badaniami w działaniu, etnografia zaangażowana współwystępuje. Perspektywa etnografów jako zaangażowanych badaczy działających $\mathrm{w}$ terenie koreluje $\mathrm{z}$ przekroczeniem czy nawet „zerwaniem z pozytywistycznym pojęciem badań naukowych wolnych od wartości" (Foley, Valenzuela, 2009, s. 318). I choć korzystanie z różnych ujęć epistemologicznych może utrudniać obiektywizm w badaniach etnograficznych, to jednak przybliża badaczy do lepszego zrozumienia problemów społecznych.

Przykładem badań etnograficznych połączonych z badaniem w działaniu jest praca Červinkovej (2013), antropologa kultury, która przeprowadziła dydaktyczny eksperyment w kształceniu nauczycieli. Badaczka osiągnęła cel, którym było wyposażenie przyszłych nauczycieli w krytyczne kompetencje ukierunkowane na samodzielne rozwijanie własnego profesjonalizmu.

\section{BibLIOGRAFIA}

[1] Angrosino, M. (2010). Badania etnograficzne i obserwacyjne. Warszawa: PWN.

[2] Bielecka-Prus, J. (2014). Po co nam autoetnografia? Krytyczna analiza autoetnografii jako metody badawczej, Przegląd Socjologii Jakościowej, 10(3), 76-95.

[3] Cervinková, H. (2012). Badania w działaniu i zaangażowana antropologia edukacyjna, Teraźniejszość - Człowiek Edukacja, 1(57), 7-18.

[4] Červinková, H. (2013). Etnografia edukacyjna i badania w działaniu - z warsztatu kształcenia nauczycieli, Forum Oświatowe, 1(48), 123-137.

[5] Cuprjak, M. (2014). Doświadczanie codzienności ucznia. Etnografia zaangażowana, Przegląd Badań Edukacyjnych, 18(1), 195-204.

[6] Dejna, D. (2012). Amisze. Fenomen wychowania endemicznego. Toruń: Wydawnictwo Adam Marszałek.

[7] Dudkiewicz, M. (2011). Metodologiczny kontekst badań aktywizujących, Zeszyty Centrum Badań Spoteczności i Polityk Lokalnych, 2(5), 4-6.

[8] Foley, D., Valenzuela, A. (2009). Etnografia krytyczna. Polityka współpracy. W: N. K. Denzin, Y. Lincoln (red.), Metody badawcze w naukach społecznych (ss. 315-339). Warszawa: PWN.

[9] Jabłoński, M. (2016). Od prakseologii do badań w działaniu. Wokół synergii i antagonizmów, Przeglad Badań Edukacyjnych, 23(2), 247-268.

[10] Kacperczyk, A. (2016). „Nie muszę się tak bać!”. Rola autoetnografii w analizie emocjonalnych aspektów działania wspinaczkowego. W: M. Kafar (red.), Autobiograficzne aspekty praktyk poznawczych (ss. 215-253). Łódź: Wydawnictwo Uniwersytetu Łódzkiego.

[11] Kacperczyk, A. (2016).Społeczne światy. Teoria - empiria - metody badań. Na przykładzie analizy społecznego świata wspinaczki. Łódź: Wydawnictwo Uniwersytetu Łódzkiego.

[12] Lewin, K. (1948). Resolving social conflicts [Rozwiązywania konfliktów społecznych], Nowy Jork: Harper \& Row.

[13] Nowotniak, J. (2011). Społeczne światy pokoi nauczycielskich, Teraźniejszość-Człowiek-Edukacja, 3(55), 71-86.

[14] Pilch, T., Bauman, T. (2010). Zasadybadań pedagogicznych, Warszawa: Wydawnictwo Akademickie „Żak”.

[15] Polak, K. (2007). Kultura szkoły. Od relacji społecznych do języka uczniowskiego. Kraków: Wydawnictwo Uniwersytetu Jagiellońskiego.

[16] Skulicz, D. (1998). Diagnozowanie pedagogiczne. W: S. Palka (red.), Orientacja w metodologii badań pedagogicznych (ss. 56). Kraków: Wydawnictwo Uniwersytetu Jagiellońskiego.

[17] Skulicz, D. (2009). Badania opisowe i badania diagnostyczne. W: S. Palka (red.), Podstawy metodologii badań w pedagogice (ss.221-236). Gdańsk: Gdańskie Wydawnictwo Psychologiczne.

[18] Woynarowska-Sołdan, M. (2014). Metoda Action Research i jej zastosowanie w promocji zdrowia, Hygeia Public Health, 49(4), 672-678. 